\title{
Sphingopyxis panaciterrulae sp. nov., isolated from soil of a ginseng field
}

Correspondence

Deok-Chun Yang

dcyang@khu.ac.kr

\author{
Sathiyaraj Srinivasan, ${ }^{1}$ Myung Kyum Kim, ${ }^{1}$ Gayathri Sathiyaraj, ${ }^{1}$ \\ Vaidyanathan Veena, ${ }^{1,2}$ Muthusamy Mahalakshmi, ${ }^{1,2}$ Senthil Kalaiselvi, ${ }^{2}$ \\ Yeon-Ju Kim ${ }^{1}$ and Deok-Chun Yang ${ }^{1}$ \\ ${ }^{1}$ Korean Ginseng Center and Ginseng Genetic Resource Bank, Kyung Hee University, \\ 1 Seocheon-dong, Giheung-gu Yongin-si, Gyeonggi-do 449-701, Republic of Korea \\ ${ }^{2}$ Dept of Biochemistry and Biotechnology, Avinashilingam University for Women, \\ Coimbatore-641012, India
}

The genus Sphingomonas has been subdivided into three different genera, Sphingobium, Novosphingobium and Sphingopyxis in addition to the genus Sphingomonas sensu stricto (Takeuchi et al., 2001). Yabuuchi et al. (2002) suggested that there was no phenotypic and phylogenetic evidence to divide the genus Sphingomonas into the four separate genera, but the nomenclature of Takeuchi et al. (2001) is commonly used (Kämpfer et al., 2002; Busse et al., 2003; Fujii et al., 2003; Godoy et al., 2003; Ushiba et al., 2003; Sohn et al., 2004). At the time of writing, the genus Sphingopyxis comprised eleven species with validly published names.

The GenBank/EMBL/DDBJ accession number for the $16 \mathrm{~S}$ rRNA gene sequence of strain DCY34 ${ }^{\top}$ is EU075217.

Tables showing the cellular fatty acid profile of strain DCY34 ${ }^{\top}$ and the results of DNA-DNA hybridization experiments and an image showing the polar lipid profile of strain $\mathrm{DCY} 34^{\top}$ are available with the online version of this paper.
In a series of studies based on a culture-dependent method, we attempted to isolate micro-organisms from soil in order to investigate the structure of the community. Strain DCY $34^{\mathrm{T}}$ was one of the isolates that was dominant on one tenth-strength R2A agar (Difco) plates incubated in aerobic conditions. The strain was characterized by a polyphasic taxonomic approach, including $16 \mathrm{~S}$ rRNA gene sequence analysis, genotypic relatedness and chemotaxonomic and phenotypic properties. The results obtained in this study indicated that DCY $34^{\mathrm{T}}$ represented a new member of the genus Sphingopyxis.

Cell morphology and motility were observed with a Nikon light microscope $(\times 1000$ magnification $)$ using cell material taken from 3-day-old colonies grown on standard R2A agar (Difco) at $30{ }^{\circ} \mathrm{C}$. Tests for the Gram reaction were performed according to the non-staining method as described by Buck (1982). Oxidase activity was evaluated via the oxidation of $1 \% p$-aminodimethylaniline oxalate. Catalase activity was determined by testing for bubble 
production after the addition of $3 \%(\mathrm{v} / \mathrm{v})$ hydrogen peroxide solution (Cappuccino \& Sherman, 2002). Growth at different temperatures $(4,15,18,25,30,37$ and $\left.42{ }^{\circ} \mathrm{C}\right)$ and $\mathrm{pH}$ values $(5.0-10.0$ at intervals of $1 \mathrm{pH}$ unit) was assessed with R2A broth. Anaerobic growth was tested using serum bottles by adding thioglycolate $\left(1 \mathrm{~g} \mathrm{l}^{-1}\right)$ to R2A broth and substituting the upper air layer with nitrogen gas. The API 20NE, API 50CH, API ZYM and API ID32 GN microtest systems were used according to the manufacturer's instructions (bioMérieux).

Isoprenoid quinones were extracted with chloroform/ methanol $(2: 1, \mathrm{v} / \mathrm{v})$, purified via TLC and analysed by HPLC, as described previously (Collins \& Jones, 1981; Shin et al., 1996). In order to analyse the methyl esters of the cellular fatty acids, the strain was grown on trypticase soy agar (TSA, Difco) for $48 \mathrm{~h}$ at $30{ }^{\circ} \mathrm{C}$ and two loopfuls of cell material was harvested. Fatty acid methyl esters were prepared, separated and identified according to the protocol of the Sherlock Microbial Identification System (MIS, MIDI, Inc.) (Sasser, 1990). Total lipids were extracted three times from $50 \mathrm{mg}$ dried cells with $5 \mathrm{ml}$ chloroform/methanol $(2: 1, \mathrm{v} / \mathrm{v})$, dried and redissolved in methanol. A portion of the extracted lipids was subjected to alkaline hydrolysis with $1 \mathrm{M} \mathrm{KOH}$ in methanol $(2: 1$, $\mathrm{v} / \mathrm{v}$ ) for $2 \mathrm{~h}$ at $40{ }^{\circ} \mathrm{C}$. The lipids were analysed according to Yabuuchi et al. (1990) by TLC with a solvent system composed of chloroform, methanol and water $(70: 30: 5$, $\mathrm{v} / \mathrm{v} / \mathrm{v})$. To determine the polar lipid profile, total cellular polar lipids were extracted and examined by twodimensional TLC (Minnikin et al., 1977). For the detection of glycolipid spots, orcine-sulfuric acid reagent $(0.2 \%$ orcinol in $2 \mathrm{M}$ sulfuric acid) was sprayed and charred at $120{ }^{\circ} \mathrm{C}$ until the maximum purple colour developed.

For the determination of the DNA $\mathrm{G}+\mathrm{C}$ content, genomic DNA was extracted and purified with the Qiagen Genomictip system 100/G (Qiagen) and enzymically degraded into nucleosides. The nucleosides were analysed using HPLC as described previously (Tamaoka \& Komagata, 1984; Mesbah et al., 1989). DNA-DNA hybridization experiments were performed fluorometrically, according to the method developed by Ezaki et al. (1989), using photobiotin-labelled DNA probes and micro-dilution wells. Hybridization was performed at $49.8{ }^{\circ} \mathrm{C}$ in the presence of $50 \%(\mathrm{v} / \mathrm{v})$ formamide with the ionic strength of $0.3 \mathrm{M} \mathrm{NaCl}$. The hybridizations were carried out reciprocally with five replications per sample. The highest and lowest values obtained for each sample were excluded; the remaining three values were utilized for the calculation of DNA-DNA hybridization values. The DNA relatedness values quoted are expressed as the means of these three values.

The 16S rRNA gene was amplified from the chromosomal DNA using the universal bacterial primer set, $\mathrm{fD} 1$ and $\mathrm{rP} 1$ (Weisburg et al., 1991) and the purified PCR product was sequenced by Genotec (Kim et al., 2005). The full sequence of the 16S rRNA gene was compiled with SeqMan software and the 16S rRNA gene sequences of related taxa were obtained from GenBank and edited using the BioEdit program (Hall, 1999). Multiple alignments were performed with the CLUSTAL_X program (Thompson et al., 1997). Evolutionary distances were calculated using the Kimura two-parameter model (Kimura, 1983). The phylogenetic tree was reconstructed via the neighbour-joining method (Saitou \& Nei, 1987) with the MEGA3 program (Kumar et al., 2004). Bootstrap analysis with 1000 replicates was also conducted in order to obtain confidence levels for the branches (Felsenstein, 1985). The closest relatives of strain DCY $34^{\mathrm{T}}$, the type strains of all of the members of the genus Sphingopyxis and closely related type species of the order Sphingomonadales were included in the phylogenetic tree.

When cultured on R2A agar (Difco) at $30{ }^{\circ} \mathrm{C}$, strain DCY $34^{\mathrm{T}}$ yielded pale yellow, circular colonies. The cells were found to be Gram-negative, motile and rod-shaped. When grown on R2A agar and $\mathrm{LB}$ agar at $30{ }^{\circ} \mathrm{C}$ for 3 days, cells were $0.2-0.5 \mu \mathrm{m}$ in diameter and $0.3-0.9 \mu \mathrm{m}$ in length. Strain DCY $34^{\mathrm{T}}$ was able to grow at $25-37^{\circ} \mathrm{C}$, but not at $4{ }^{\circ} \mathrm{C}$ or $42{ }^{\circ} \mathrm{C}$. The optimum growth temperature range was 25 to $30{ }^{\circ} \mathrm{C}$. The results of the physiological tests for strain $\mathrm{DCY} 34^{\mathrm{T}}$ are summarized in the species description. The characteristics of strain DCY $34^{\mathrm{T}}$ are compared with those of related type strains of species of the genus Sphingopyxis in Table 1.

The cellular fatty acid contents of strain DCY $34^{\mathrm{T}}$ included $\mathrm{C}_{18: 1} \omega 7 c(27.5 \%)$, summed feature $4\left(\mathrm{C}_{16: 1} \omega 7 c\right.$ and/or $\mathrm{C}_{15: 0}$ iso $\left.2-\mathrm{OH} ; 18.6 \%\right), \mathrm{C}_{16: 0}(15.6 \%)$, summed feature 8 $\left(\mathrm{C}_{19: 1} \omega 6 c\right.$ and/or unknown $\left.18.864 ; 15.4 \%\right)$ and $\mathrm{C}_{17: 1} \omega 6 c$ $(7.3 \%)$. The cellular fatty acid profiles of strain DCY $34^{\mathrm{T}}$ and those of closely related type strains are shown in Supplementary Table S1 (available with IJSEM Online). The fatty acid profile of the strain DCY $34^{\mathrm{T}}$ was very similar to those of other type strains, but contained different amounts of fatty acids. The presence of $\mathrm{C}_{18: 1} \omega 7 c, \mathrm{C}_{16: 0}$ and summed feature 4 as the major fatty acids is a characteristic feature of the genus Sphingopyxis (Takeuchi et al., 2001). The characteristic difference between strain DCY $34^{\mathrm{T}}$ and the other type strains of the genus Sphingopyxis was the absence of the minor fatty acid $\mathrm{C}_{16: 0}$ 2-OH, which is generally found in members of this genus (see Supplementary Table S1). Strain DCY $34^{\mathrm{T}}$ contained ubiquinone Q-10 as the predominant respiratory lipoquinone. Alkaline stable sphingoglycolipid was identified in strain DCY $34^{\mathrm{T}}$ which clearly suggested that the bacterium belonged to the $\alpha-4$ subclass of the Proteobacteria. The overall polar lipid pattern of strain DCY $34^{\mathrm{T}}$ corresponded to those reported previously for sphingomonads (Busse et al., 1999) and was composed of phosphatidylethanolamine, diphosphatidylglycerol, phosphatidylglycerol, phosphatidylcholine, sphingoglycolipid and an unknown polar lipid (see Supplementary Fig. S1 in IJSEM Online).

An almost-complete sequence (1432 bp) of the 16S rRNA gene of strain DCY $34^{\mathrm{T}}$ was used for phylogenetic analysis. 
Table 1. Differential phenotypic characteristics between strain DCY $34^{\top}$ and closely related species of the genus Sphingopyxis

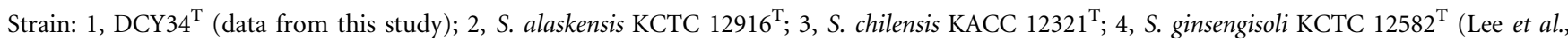
2008); 5, S. macrogoltabida KACC $10927^{\mathrm{T}}$; 6, S. taejonensis KCTC $2884^{\mathrm{T}} ; 7$, S. witflariensis KCTC $12115^{\mathrm{T}}$. All strains are motile and catalase and oxidase-positive. All strains are Gram-negative, cannot produce indole and are negative for the assimilation of caprate and mannitol. Data were obtained during this study under identical growth conditions, except where indicated otherwise. +, Positive; - , negative; v, variable; w, weakly positive; B, beige; BY, bright yellow; Y, yellow; PY, pale yellow; WB, whitish brown; WG, weak growth; NA, not available.

\begin{tabular}{|c|c|c|c|c|c|c|c|}
\hline Characteristic & 1 & 2 & 3 & 4 & 5 & 6 & 7 \\
\hline Morphology & Rod & Short rod & Rod & Rod & Rod & Rod & Rod \\
\hline Colony colour & PY & $\mathrm{Y}-\mathrm{B}$ & Y & Y & WB-Y & PY & BY \\
\hline \multicolumn{8}{|l|}{ Growth at (R2A): } \\
\hline $4{ }^{\circ} \mathrm{C}$ & - & + & WG & + & - & WG & - \\
\hline $42{ }^{\circ} \mathrm{C}$ & + & + & WG & + & + & + & - \\
\hline pH 11 & + & - & - & - & + & - & - \\
\hline \multicolumn{8}{|l|}{ Enzyme activity (API ZYM): } \\
\hline$N$-Acetyl- $\beta$-glucosaminidase & + & + & - & - & + & - & - \\
\hline Acid phosphatase & + & + & + & $\mathrm{w}$ & - & + & + \\
\hline Alkaline phosphatase & + & $\mathrm{w}$ & + & $\mathrm{w}$ & $\mathrm{w}$ & + & + \\
\hline$\alpha$-Chymotrypsin & - & $\mathrm{w}$ & - & - & + & - & - \\
\hline Cystine arylamidase & + & - & + & $\mathrm{w}$ & - & $\mathrm{w}$ & - \\
\hline$\alpha$-Galactosidase & - & + & $\mathrm{w}$ & $\mathrm{w}$ & $\mathrm{w}$ & $\mathrm{w}$ & $\mathrm{w}$ \\
\hline$\alpha$-Glucosidase (starch hydrolysis) & + & $\mathrm{W}$ & + & + & - & + & + \\
\hline$\beta$-Galactosidase (PNPG) & - & + & - & - & + & - & + \\
\hline$\beta$-Glucosidase (aesculin hydrolysis) & + & + & + & + & + & $\mathrm{w}$ & - \\
\hline Leucine arylamidase & + & $\mathrm{w}$ & + & + & + & + & $\mathrm{w}$ \\
\hline Lipase $(\mathrm{C} 14)$ & - & + & $\mathrm{w}$ & - & $\mathrm{w}$ & - & - \\
\hline$\alpha$-Mannosidase & - & - & + & + & - & + & - \\
\hline Naphthol-AS-BI-phosphohydrolase & + & - & + & + & + & + & + \\
\hline Trypsin & + & - & + & $\mathrm{w}$ & - & $\mathrm{w}$ & + \\
\hline Urease & - & + & - & - & - & - & - \\
\hline Valine arylamidase & + & + & + & $\mathrm{w}$ & + & $\mathrm{w}$ & $\mathrm{w}$ \\
\hline \multicolumn{8}{|l|}{ Fermentation of sugars (API $50 \mathrm{CH}$ ): } \\
\hline$N$-Acetylglucosamine & + & - & + & $\mathrm{w}$ & - & - & - \\
\hline Aesculin & + & + & + & $\mathrm{w}$ & - & - & - \\
\hline Mannitol & - & - & - & - & - & $\mathrm{w}$ & - \\
\hline D-Mannose & - & - & + & $\mathrm{w}$ & - & - & - \\
\hline \multicolumn{8}{|l|}{ Assimilation tests (API ID32 GN): } \\
\hline Acetate & - & - & - & - & + & - & - \\
\hline$N$-Acetyl-D-glucosamine & + & - & - & + & - & $\mathrm{w}$ & - \\
\hline Adipate & - & + & + & $\mathrm{w}$ & - & + & - \\
\hline L-Histidine & - & + & $\mathrm{w}$ & + & $\mathrm{w}$ & - & + \\
\hline 3-Hydroxybenzoate & - & + & $\mathrm{w}$ & $\mathrm{w}$ & + & + & + \\
\hline 4-Hydroxybenzoate & - & + & - & - & $\mathrm{w}$ & - & - \\
\hline DL-3-Hydroxybutyrate & - & + & $\mathrm{w}$ & + & - & - & $\mathrm{w}$ \\
\hline Itaconate & + & - & + & - & + & + & $\mathrm{w}$ \\
\hline DL-Lactate & - & - & $\mathrm{w}$ & + & + & - & - \\
\hline L-Malate & + & + & + & $\mathrm{w}$ & - & + & - \\
\hline Malonate & - & $\mathrm{W}$ & - & - & $\mathrm{W}$ & - & + \\
\hline D-Mannose & - & - & + & $\mathrm{w}$ & - & - & - \\
\hline L-Proline & + & $\mathrm{w}$ & + & $\mathrm{w}$ & - & - & + \\
\hline Propionate & - & + & - & - & + & + & - \\
\hline L-Rhamnose & + & - & + & $\mathrm{W}$ & $\mathrm{W}$ & $\mathrm{W}$ & - \\
\hline D-Ribose & $\mathrm{w}$ & - & - & $\mathrm{w}$ & - & - & - \\
\hline Salicin & - & - & + & + & - & + & - \\
\hline L-Serine & - & $\mathrm{w}$ & + & + & - & + & - \\
\hline Suberate & - & $\mathrm{w}$ & $\mathrm{w}$ & $\mathrm{w}$ & $\mathrm{w}$ & $\mathrm{w}$ & + \\
\hline Sucrose & + & - & $\mathrm{w}$ & - & + & + & - \\
\hline$n$-Valerate & - & + & - & - & $\mathrm{w}$ & - & - \\
\hline
\end{tabular}


Table 1. cont.

\begin{tabular}{|lccccccc|}
\hline Characteristic & $\mathbf{1}$ & $\mathbf{2}$ & $\mathbf{3}$ & $\mathbf{4}$ & $\mathbf{5}$ & $\mathbf{6}$ & $\mathbf{7}$ \\
\hline Quinone $^{*}$ & $\mathrm{Q}-10$ & $\mathrm{Q}-10^{a}$ & $\mathrm{Q}-10^{b}$ & $\mathrm{Q}-10^{a}$ & $\mathrm{Q}^{a}-10^{d}$ & $\mathrm{Q}-10^{e}$ & $\mathrm{Q}-10,8^{f}$ \\
DNA G + C content $^{*}$ & 62.3 & $65.0^{c}$ & $66.0^{c}$ & $69.2^{c}$ & $63-65^{c}$ & $63.0^{c}$ & $\mathrm{NA}^{c}$ \\
\hline
\end{tabular}

*Data from other studies as indicated: $a$, Vancanneyt et al. (2001); b, Godoy et al. (2003); c, Lee et al. (2008); d, Takeuchi et al. (2001); e, Pal et al. (2006); f, Kämpfer et al. (2002).

Strain DCY $34^{\mathrm{T}}$ belonged to the class Alphaproteobacteria, the order Sphingomonadales and the family Sphingomonadaceae. The highest degree of sequence similarity was found with Sphingopyxis witflariensis $\mathrm{W}-50^{\mathrm{T}}(97.1 \%)$, Sphingopyxis ginsengisoli Gsoil $250^{\mathrm{T}}(97.0 \%)$, Sphingopyxis chilensis $\mathrm{S} 37^{\mathrm{T}}$ (96.9\%), Sphingopyxis macrogoltabida IFO $15033^{\mathrm{T}}(96.8 \%)$, Sphingopyxis alaskensis RB2256 ${ }^{\mathrm{T}}(96.7 \%)$ and Sphingopyxis taejonensis $\mathrm{JSS} 54^{\mathrm{T}}$ (96.7\%). As shown in the phylogenetic tree (Fig. 1), strain DCY $34^{\mathrm{T}}$ clearly belonged to the genus Sphingopyxis lineage, as evidenced by the high bootstrap value. Based on $16 \mathrm{~S}$ rRNA gene sequencing, the phylogenetic position of strain DCY $34^{\mathrm{T}}$ among members of the family Sphingomonadaceae was unique and distinct. The $\mathrm{G}+\mathrm{C}$ content of the genomic DNA of strain $\mathrm{DCY} 34^{\mathrm{T}}$ was $62.3 \mathrm{~mol} \%$ and was similar to that found for other species of the genus Sphingopyxis (58-66 mol\%). DNA-DNA hybridization studies were performed to differentiate strain DCY $34^{\mathrm{T}}$ from the closely related species of the genus Sphingopyxis. Strain DCY $34^{\mathrm{T}}$ exhibited relatively low levels of DNA-DNA relatedness (see Supplementary Table S2) with respect to $S$. alaskensis KCTC $12916^{\mathrm{T}}(19 \%)$, S. chilensis KACC $12321^{\mathrm{T}}$
(4\%), S. ginsengisoli KCTC $12582^{\mathrm{T}}$ (39\%), S. macrogoltabida KACC $10927^{\mathrm{T}}(1 \%)$, S. taejonensis KCTC $2884^{\mathrm{T}}(6 \%)$ and $S$. witflariensis KCTC $12115^{\mathrm{T}}(48 \%)$, thus indicating that it constituted a separate species (Wayne et al., 1987).

The results of the phenotypic and phylogenetic characterizations indicated that strain DCY $34^{\mathrm{T}}$ belonged to the genus Sphingopyxis. The phylogenetic distinctiveness, together with DNA-DNA hybridization data, confirmed that the new strain represented a novel species that was distinct from recognized members of the genus Sphingopyxis. Therefore, on the basis of the data presented, strain DCY $34^{\mathrm{T}}$ should be classified as representing a novel species of the genus Sphingopyxis, for which the name Sphingopyxis panaciterrulae sp. nov. is proposed.

\section{Description of Sphingopyxis panaciterrulae sp. nov.}

Sphingopyxis panaciterrulae (pa.na.ci.ter.ru'la.e. N.L. n. Panax -acis scientific name of ginseng; L. fem. n. terrula a field; N.L. gen. n. panaciterrulae of a ginseng field).

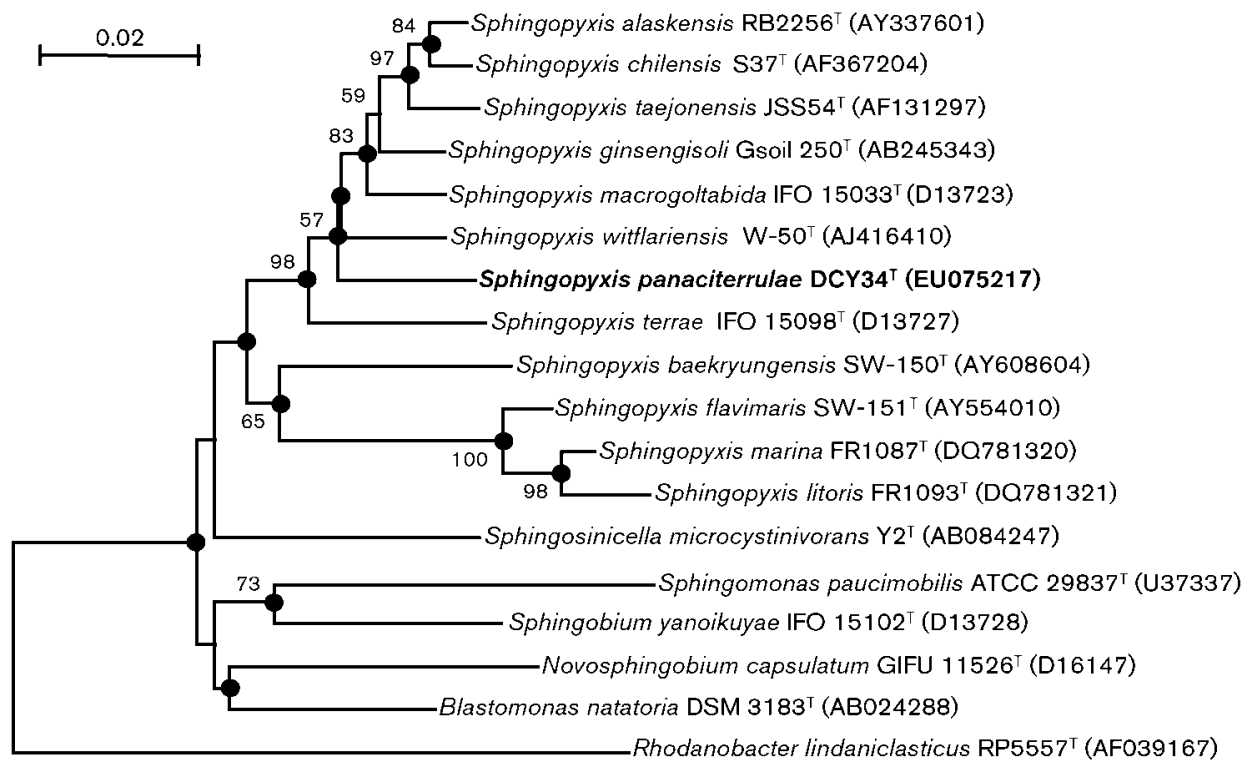

Fig. 1. Phylogenetic tree based on $16 \mathrm{~S}$ rRNA gene sequences, showing the phylogenetic relationships between strain $\mathrm{DCY} 34^{\top}$ and related species (all species of the genus Sphingopyxis and other related genera). The neighbour-joining method was used. Bootstrap values (expressed as percentages of 1000 replications) $>50 \%$ are shown at the branch points. Filled circles indicate generic branches that were also recovered by using maximum-parsimony algorithms. Bar, 0.02 substitutions per nucleotide position. 
Gram-negative, motile rod when grown on R2A agar (Difco) at $30{ }^{\circ} \mathrm{C}$ for 3 days. Colonies are circular and pale yellow in colour. Optimal growth temperature is $25-30{ }^{\circ} \mathrm{C}$ and the optimum $\mathrm{pH}$ is 7.0-8.0. Both oxidase and catalase are positive. Acid is produced from D-glucose. Indole is not produced and nitrate is not reduced. Does not grow anaerobically in R2A broth medium supplemented with nitrate. Assimilates $\mathrm{N}$-acetylglucosamine, D-glucose, itaconate, malate, maltose, L-rhamnose and sucrose. The following carbon sources are not assimilated: adipate, Lalanine, L-arabinose, caprate, citrate, L-fucose, gluconate, glycogen, L-histidine, 3-hydroxybenzoate, 4-hydroxybenzoate, 3-hydroxybutyric acid, inositol, lactate, D-mannitol, mannose, melibiose, phenylacetate, potassium 5-ketogluconate, propionate, potassium 2-ketogluconate, L-proline, D-ribose, salicin, L-serine, sodium acetate, sodium malonate, D-sorbitol, suberate and valerate. Produces acid phosphatase, $N$-acetyl- $\beta$-glucosaminidase, alkaline phosphatase, cystine arylamidase, esterase (C4), esterase lipase (C8), $\alpha$-glucosidase, $\beta$-glucosidase (aesculin hydrolysis), naphthol-AS-BI-phosphohydrolase, leucine arylamidase, trypsin and valine arylamidase, but does not produce arginine dihydrolase, $\alpha$-chymotrypsin, $\alpha$-fucosidase, $\alpha$ galactosidase, $\beta$-galactosidase, $\beta$-glucuronidase, lipase (C14), $\alpha$-mannosidase, protease (gelatin hydrolysis) or urease. Ubiquinone Q-10 is the predominant respiratory lipoquinone. The cellular fatty acids include $\mathrm{C}_{18: 1} \omega 7 c$, summed feature $4\left(\mathrm{C}_{16: 1} \omega 7 \mathrm{c}\right.$ and/or $\mathrm{C}_{15: 0}$ iso $\left.2-\mathrm{OH}\right)$, $\mathrm{C}_{16: 0}$, summed feature $8 \quad\left(\mathrm{C}_{19: 1} \omega 6 c\right.$ and/or unknown $18.864)$ and $\mathrm{C}_{17: 1} \omega 6 c(7.3 \%)$. The major polar lipids are phosphatidylethanolamine, diphosphatidylglycerol, phosphatidylglycerol, phosphatidylcholine, sphingoglycolipid and an unknown polar lipid.

The type strain, DCY $34^{\mathrm{T}}\left(=\right.$ KCTC $22112^{\mathrm{T}}=$ JCM $\left.14844^{\mathrm{T}}\right)$, was isolated from soil of a ginseng field in Daejeon, South Korea. The DNA $\mathrm{G}+\mathrm{C}$ content of the type strain is $62.3 \mathrm{~mol} \%$ as determined by HPLC.

\section{Acknowledgements}

This study was supported by KGCMVP for Technology Development Program of Agriculture and Forestry, Ministry of Agriculture and Forestry, Republic of Korea.

\section{References}

Buck, J. D. (1982). Nonstaining ( $\mathrm{KOH})$ method for determination of Gram reactions of marine bacteria. Appl Environ Microbiol 44, 992993.

Busse, H.-J., Kämpfer, P. \& Denner, E. B. (1999). Chemotaxonomic characterisation of Sphingomonas. J Ind Microbiol Biotechnol 23, 242251.

Busse, H.-J., Denner, E. B. M., Buczolits, S., Salkinoja-Salonen, M., Bennasar, A. \& Kämpfer, P. (2003). Sphingomonas aurantiaca sp. nov., Sphingomonas aerolata sp. nov. and Sphingomonas faeni sp. nov., air- and dustborne and Antarctic, orange-pigmented, psychrotolerant bacteria, and emended description of the genus Sphingomonas. Int $J$ Syst Evol Microbiol 53, 1253-1260.
Cappuccino, J. G. \& Sherman, N. (2002). Microbiology: a Laboratory Manual, 6th edn. Menlo Park, CA: Benjamin/Cummings.

Collins, M. D. \& Jones, D. (1981). Distribution of isoprenoid quinone structural types in bacteria and their taxonomic implications. Microbiol Rev 45, 316-354.

Ezaki, T., Hashimoto, Y. \& Yabuuchi, E. (1989). Fluorometric deoxyribonucleic acid-deoxyribonucleic acid hybridization in microdilution wells as an alternative to membrane filter hybridization in which radioisotopes are used to determine genetic relatedness among bacterial strains. Int J Syst Bacteriol 39, 224-229.

Felsenstein, J. (1985). Confidence limits on phylogenies: an approach using the bootstrap. Evolution 39, 783-791.

Fujii, K., Satomi, M., Morita, N., Motomura, T., Tanaka, T. \& Kikuchi, S. (2003). Novosphingobium tardaugens sp. nov., an oestradiol-degrading bacterium isolated from activated sludge of a sewage treatment plant in Tokyo. Int J Syst Evol Microbiol 53, 47-52.

Godoy, F., Vancanneyt, M., Martínez, M., Steinbüchel, A., Swings, J. \& Rehm, B. H. A. (2003). Sphingopyxis chilensis sp. nov., a chlorophenol-degrading bacterium that accumulates polyhydroxyalkanoate, and transfer of Sphingomonas alaskensis to Sphingopyxis alaskensis comb. nov. Int J Syst Evol Microbiol 53, 473-477.

Hall, T. A. (1999). BioEdit: a user-friendly biological sequence alignment editor and analysis program for Windows 95/98/NT. Nucleic Acids Symp Ser 41, 95-98.

Kämpfer, P., Witzenberger, R., Denner, E. B. M., Busse, H.-J. \& Neef, A. (2002). Sphingopyxis witflariensis sp. nov., isolated from activated sludge. Int J Syst Evol Microbiol 52, 2029-2034.

Kim, M. K., Im, W.-T., Ohta, H., Lee, M. \& Lee, S.-T. (2005). Sphingopyxis granuli sp. nov., a $\beta$-glucosidase-producing bacterium in the family Sphingomonadaceae in $\alpha-4$ subclass of the Proteobacteria. J Microbiol 43, 152-157.

Kimura, M. (1983). The Neutral Theory of Molecular Evolution. Cambridge: Cambridge University Press.

Kumar, S., Tamura, K. \& Nei, M. (2004). MEGA3: Integrated software for molecular evolutionary genetics analysis and sequence alignment. Brief Bioinform 5, 150-163.

Lee, M., Ten, L. N., Lee, H. W., Oh, H. W., Im, W. T. \& Lee, S. T. (2008). Sphingopyxis ginsengisoli sp. nov., isolated from soil of a ginseng field in South Korea. Int J Syst Evol Microbiol 58, 2342-2347.

Mesbah, M., Premachandran, U. \& Whitman, W. B. (1989). Precise measurement of the $\mathrm{G}+\mathrm{C}$ content of deoxyribonucleic acid by highperformance liquid chromatography. Int J Syst Bacteriol 39, 159-167.

Minnikin, D. E., Patel, P. V., Alshamaony, L. \& Goodfellow, M. (1977). Polar lipid composition in the classification of Nocardia and related bacteria. Int J Syst Bacteriol 27, 104-117.

Pal, R., Bhasin, V. K. \& Lal, R. (2006). Proposal to reclassify [Sphingomonas] xenophaga Stolz et al. 2000 and [Sphingomonas] taejonensis Lee et al. 2001 as Sphingobium xenophagum comb. nov. and Sphingopyxis taejonensis comb. nov., respectively. Int J Syst Evol Microbiol 56, 667-670.

Saitou, N. \& Nei, M. (1987). The neighbor-joining method: a new method for reconstructing phylogenetic trees. Mol Biol Evol 4, 406425.

Sasser, M. (1990). Identification of bacteria by gas chromatography of cellular fatty acids, MIDI Technical Note 101. Newark, DE: MIDI Inc.

Shin, Y. K., Lee, J.-S., Chun, C. O., Kim, H.-J. \& Park, Y.-H. (1996). Isoprenoid quinone profiles of the Leclercia adecarboxylata KCTC $1036^{\mathrm{T}}$. J Microbiol Biotechnol 6, 68-69.

Sohn, J. H., Kwon, K. K., Kang, J. H., Jung, H. B. \& Kim, S. J. (2004). Novosphingobium pentaromativorans sp. nov., a high-molecular-mass 
polycyclic aromatic hydrocarbon-degrading bacterium isolated from estuarine sediment. Int J Syst Evol Microbiol 54, 1483-1487.

Takeuchi, M., Hamana, K. \& Hiraishi, A. (2001). Proposal of the genus Sphingomonas sensu stricto and three new genera, Sphingobium, Novosphingobium and Sphingopyxis, on the basis of phylogenetic and chemotaxonomic analyses. Int J Syst Evol Microbiol 51, 1405-1417.

Tamaoka, J. \& Komagata, K. (1984). Determination of DNA base composition by reversed-phase high-performance liquid chromatography. FEMS Microbiol Lett 25, 125-128.

Thompson, J. D., Gibson, T. J., Plewniak, F., Jeanmougin, F. \& Higgins, D. G. (1997). The CLUSTAL_X windows interface: flexible strategies for multiple sequence alignment aided by quality analysis tools. Nucleic Acids Res 25, 4876-4882.

Ushiba, Y., Takahara, Y. \& Ohta, H. (2003). Sphingobium amiense sp. nov., a novel nonylphenol-degrading bacterium isolated from a river sediment. Int J Syst Evol Microbiol 53, 2045-2048.

Vancanneyt, M., Schut, F., Snauwaert, C., Goris, J., Swings, J. \& Gottschal, J. C. (2001). Sphingomonas alaskensis sp. nov., a dominant bacterium from a marine oligotrophic environment. Int J Syst Evol Microbiol 51, 73-79.
Wayne, L. G., Brenner, D. J., Colwell, R. R., Grimont, P. A. D., Kandler, O., Krichevsky, M. I., Moore, L. H., Moore, W. E. C., Murray, R. G. E. \& other authors (1987). International Committee on Systematic Bacteriology. Report of the ad hoc committee on reconciliation of approaches to bacterial systematics. Int J Syst Bacteriol 37, 463464.

Weisburg, W. G., Barns, S. M., Pelletier, D. A. \& Lane, D. J. (1991). 16 S ribosomal DNA amplification for phylogenetic study. J Bacteriol 173, 697-703.

Yabuuchi, E., Yano, I., Oyaizu, H., Hashimoto, Y., Ezaki, T. \& Yamamoto, H. (1990). Proposals of Sphingomonas paucimobilis gen. nov. and comb. nov., Sphingomonas parapaucimobilis sp. nov., Sphingomonas yanoikuyae sp. nov., Sphingomonas adhaesiva sp. nov., Sphingomonas capsulata comb. nov., and two genospecies of the genus Sphingomonas. Microbiol Immunol 34, 99-119.

Yabuuchi, E., Kosako, Y., Fujiwara, N., Naka, T., Matsunaga, I., Ogura, H. \& Kobayashi, K. (2002). Emendation of the genus Sphingomonas Yabuuchi et al. 1990 and junior objective synonymy of the species of three genera, Sphingobium, Novosphingobium and Sphingopyxis, in conjunction with Blastomonas ursincola. Int J Syst Evol Microbiol 52, 1485-1496. 